\title{
Retraction: Rapamycin-loaded nanoparticles for inhibition of neointimal hyperplasia in experimental vein grafts
}

\author{
Junjie Zou' ${ }^{1}$ Xiwei Zhang ${ }^{1}$, Hongyu Yang ${ }^{1}$, Yi Zhu ${ }^{2}$, Hao Ma ${ }^{1}$ and Shui Wang ${ }^{2 *}$
}

\section{Retraction}

This article [Zou et al., Journal of Cardiothoracic Surgery 2011, 6:69] has been retracted at the request of the Editor [1]. Although the authors withdrew their submission the article was subsequently transmitted to the journal's production department, which resulted in it being published in error.

\section{Author details}

'Department of General Surgery, the First Affiliated Hospital of Nanjing Medical University, Nanjng, Jiangsu province, China. ${ }^{2}$ Division of Vascular Surgery, Department of General Surgery, the First Affiliated Hospital of Nanjing Medical University, Nanjng, Jiangsu province, China.

Received: 5 March 2012 Accepted: 6 March 2012

Published: 6 March 2012

\section{Reference}

1. Zou J, Zhang X, Yang H, Zhu Y, Ma H, Wang S: Rapamycin-loaded nanoparticles for inhibition of neointimal hyperplasia in experimental vein grafts. Journal of Cardiothoracic Surgery 2011, 6:69.

doi:10.1186/1749-8090-7-17

Cite this article as: Zou et al:: Retraction: Rapamycin-loaded

nanoparticles for inhibition of neointimal hyperplasia in experimental vein grafts. Journal of Cardiothoracic Surgery 2012 7:17.

* Correspondence: wishlucky@163.com

${ }^{2}$ Division of Vascular Surgery, Department of General Surgery, the First Affiliated Hospital of Nanjing Medical University, Nanjng, Jiangsu province, China

Full list of author information is available at the end of the article

Submit your next manuscript to BioMed Central and take full advantage of:

- Convenient online submission

- Thorough peer review

- No space constraints or color figure charges

- Immediate publication on acceptance

- Inclusion in PubMed, CAS, Scopus and Google Scholar

- Research which is freely available for redistribution 